\title{
POLR3B Gene
}

National Cancer Institute

\section{Source}

National Cancer Institute. POLR3B Gene. NCI Thesaurus. Code C131588.

This gene is involved in the synthesis of small RNAs. 